\title{
The effects of kangaroo mother care in a sample of preterm, preschool aged children
}

\section{BACKGROUND}

The research has shown that kangaroo mother care has a protective impact both on health and future cognitive skills of prematurely born babies. The aim of this study was to investigate the relation between the early skin-toskin contact and the cognitive and emotional-social functioning of preschool aged preterm babies.

\section{PARTICIPANTS AND PROCEDURE}

The study group included 99 preterm babies. The children participated in a psychological examination conducted using the Columbia Mental Maturity Scale and the Terman-Merrill Test. The data concerning the skin-to-skin contact during the child's hospitalisation were acquired during interviews with mothers. The emotional development was assessed on the basis of interviews with mothers, conducted using the Rescorla DSM-IV Orientation Scale (2005).

\section{RESULTS}

The study showed no relation between kangaroo mother care and cognitive development. Nevertheless the early skin-to-skin contact turned out to be connected with the emotional functioning of the subjects. Preterm babies who used to experience kangaroo mother care experienced fewer anxiety and depressive disorders than those who did not. In addition it was revealed that the children who suffered from early damage to the brain in the forms of intraventricular and periventricular haemorrhages and experienced kangaroo mother care demonstrated less intense depressive symptoms than those who did not.

\section{CONCLUSIONS}

The obtained results, combined with the review of the foreign literature of the subject, indicate the usefulness of introducing kangaroo mother care to neonatal wards and encouraging parents to care about their prematurely born babies in such a way.

\section{KEY WORDS}

preterm birth; kangaroo mother care; emotional development; preschool aged children 


\section{BACKGROUND}

A preterm birth, on the global scale, is the principal cause of deaths of neonates, as well as the disability of a child in the further course of their life (Engmann, Wall, Darmstadt, Valsangkar, \& Claeso, 2013). Every year, the complications that are the consequences of a preterm birth result in the deaths of more than one million children: depending on the source, a preterm birth is responsible, in a global view, for between 35\% and $50 \%$ of the deaths of neonates (Engmann et al., 2013; Blencowe et al., 2012). The research shows that the implementation of kangaroo mother care in developing countries, in which the financial possibilities to provide appropriate care (including incubators) for all children who need it are non-existent, might prevent 450,000 deaths every year (Engmann et al., 2013). In Ethiopian hospitals, the introduction of kangaroo mother care provided by mothers was connected with improvement in the survival rate: of children in a similar medical situation and having a similar birth weight, $77.5 \%$ of children taking advantage of kangaroo mother care survived, in comparison with $62 \%$ of children treated with the use of standard methods (Worku \& Kassie, 2005). In Nicaragua, children were monitored after the introduction of the procedure of kangaroo mother care in hospitals: in comparison with the earlier period (preceding the introduction of kangaroo mother care), children subjected to kangaroo mother care were hospitalized for a shorter period of time (on average, shorter by 4.5 days), and $71 \%$ of them were solely breast fed (Broughton, Gomez, Sanchez, \& Vindell, 2013). In the research referred to above, there was also a reduction of costs connected with the shorter time of being hospitalized, the elimination of the use of an incubator, and the lack of the need for antibiotic treatment that were observed. That fact is of major importance for countries with a low level of personal income, in which it may be difficult to gain access to specialist medical care. In turn, in countries in which access to specialist neonatal care is not a problem commonly, kangaroo mother care fulfils an important role in the elimination of the results of early separation of the parents and their child. Kangaroo mother care exerts an influence both on the development of preterm infants and on the mental condition of their mothers. In the group of mothers who used kangaroo mother care, lower levels of depression and anxiety were observed, and children were perceived by mothers in a more positive light; mothers using kangaroo mother care showed more attachment behaviours towards the neonates (Feldman, Weller, Sirota, \& Eidelman, 2002; Nyqvist et al., 2010; Feldman, Rosenthal, \& Eidelman, 2014; Barratt, Roach, \& Leavitt, 1992; Brooten et al., 1988). The review of the literature shows that the protective influence exerted by kangaroo mother care on the development of a child is connected with the influence of touch on the maturing of the autonomic nervous system, and on the elimination of the level of stress experienced by neonates (Hofer, 1987; Feldman et al., 2014). The autonomic nervous system matures by means of thermal, tactile stimulation provided by the caregiver of a child (Hofer, 1987; Feldman et al., 2014). To provide an example, the sleep and wake rhythm is formed by the behavioural and physiological rhythms of the mother, and kangaroo mother care helps to regulate the daily rhythm of the activity of a child (Hofer \& Shair, 1982), thus, providing a protection for the developing nervous system. That fact is confirmed by longitudinal studies: a regulated sleep and wake rhythm in preterm infants at the time of the planned birth is connected with the better cognitive functioning of them at the beginning of the school education period; in the group of children provided with kangaroo mother care, better results in tests assessing cognitive skills, and also executive functions, are observed (Feldman et al., 2014; Beckwith \& Parmelee, 1986; Feldman et al., 2002). The protective function of kangaroo mother care in the aspect of the cognitive development of preterm infants is a very significant one, because the research shows greater cognitive difficulties in this group of children (Bidzan \& Bieleninik, 2013; Bidzan, Bieleninik, \& Lipowska, 2013; Chrzan-Dętkoś \& Bogdanowicz, 2009; Bhutta, Cleves, Casey, Cradock, \& Anand, 2002; Chrzan-Dętkoś, 2012)

In addition, kangaroo mother care helps to eliminate the stress experienced by a neonate in connection with being hospitalized. Anand and Scalzo (2000) found in their research that the stress experienced by a child changes the physiology of their brain. In accordance with the analyses conducted by Barker and Rutter (1995), it is already as soon as upon the admission into the neonatal intensive care ward that a neonate is subjected, on average, to 60 procedures, some of which may be described as painful and invasive. Research with the use of animal models shows that if the hypothalamic-pituitary-adrenal (HPA) axis is activated with excessive frequency, the activity of the receptors in the hippocampus is inhibited, which results in the reduction of the number of receptors. The consequence of that fact is increased difficulty in self-regulation, and, in the long term, restricting adaptation skills (Gerhardt, 2010; Hofer \& Shair, 1982; Feldman et al., 2014). Exposure to an intensive and constant stress in the course of the dynamic development of the brain, in combination with the lack of protective factors, among others, in contacts with the mother, seems to exert some degree of influence on the development of neonates. An example of that is the research of the Glover team, conducted in 2003. In the group of four-week old preterm infants, born before the $32^{\text {nd }}$ week of pregnancy, who were still staying at the neonatal intensive care ward, sequences of a high level of cortisol in the blood were
The effects of kangaroo mother care 
observed. It was presumed that it was a response to the stress experienced in the course of being hospitalized. Afterwards, the level of cortisol was examined in the preterm infants after they had been discharged home - in the course of routine vaccinations. The preterm infants had a significantly higher level of cortisol after a vaccination. The effect of sensitization of the HPA axis to the stress response was observed in the eighth month of their lives as well (Glover, Miles, Matta, Modi, \& Stevenson, 2003). Other research (Grunau et al., 2010) shows that this effect occurs principally in the case of boys. The organization of the functioning of the HPA axis is, however, dependent on the contact between the mother and the child, and physical contact may have a significant protective function, lowering the stress of a preterm infant being hospitalized, and being conducive to the development of their self-regulation skills (Feldman et al., 2014). Kangaroo mother care makes it possible to eliminate stress in the case of a child, and, as well as that, acts as a non-pharmacological painkiller (Johnston et al., 2003; Johnston et al., 2009; Johnston et al., 2008).

The advantages resulting from kangaroo mother care connected with the lowering of the level of stress, as well as with the support of the development of skills connected with self-regulation, may be particularly significant for children who experienced early damage to the brain. Sostek, Smith, Katz, and Grant (1987, quoting: Cox, Hopkins, \& Hans, 2000), suggested in their work that a risk factor for the development of an unsafe attachment may be damage to the central nervous system (CNS). In their research, those authors concentrated on children who had suffered from early damage to the brain in the forms of intraventricular and periventricular haemorrhage (IVH/PVH). The risk of the occurrence of IVH reaches the highest level in the case of the most immature neonates, born before the $29^{\text {th }}$ week of fetal life (Helwich, 2002). The reason for haemorrhages is changes in the blood pressure, for example, a sudden increase in arterial or venous blood pressure. The intensity and extensive character of a haemorrhage are assessed using a four-degree scale, and the percentage of neurological consequences is determined by the extent of a haemorrhage. The cases of IVH of the first, and also of the second degree, are most frequently accompanied by mild neurological problems, whereas those of the third and fourth degrees are connected with serious neurological problems, and with psycho-motor development retardation (Garcia-Coll, Emmons, \& Vohr, 1988). Children who have experienced intraventricular and periventricular haemorrhages, even of a small extent, to a smaller degree react to their environment, and experience greater difficulties connected with participation in social relationships than the preterm infants who have not experienced effusions (Garcia-Coll et al.,
1988; Hopkins et al., 1998, quoting: Cox et al., 2000; Brisch et al., 2005). In accordance with the opinion of Cox et al. (2000), these difficulties, in combination with the conditions in the family environment, may be connected with the development of a disorganized attachment, which is a risk factor for the occurrence of various further psychopathological disorders (Gerhardt, 2010). In the case of children who had suffered from early damage to the brain, kangaroo mother care, by means of exerting an influence on both the mental welfare of mothers and the maturing nervous system, and, connected with that, increased capacities of a child in the scope of coping with stimuli, might have a significant protective function in the emotional development of children.

To summarize, the review of the literature indicates that the excessive stimulation of a neonate, connected, for example, with the pain or stress being experienced, and also with invasive medical procedures, as well as with the lack of adequate stimulation resulting from separation from their mother, may result in negative consequences in adulthood, whereas kangaroo mother care may have a significant protective function, influencing the immunity of a child.

The objective of our own research was to investigate the consequences (or the lack of them) of kangaroo mother care for the cognitive and emotional development of preterm infants at nursery school age.

The review of the literature conducted by the authors resulted in asking the following research questions:

1. Will it be possible to observe, in a nursery school period, differences in the cognitive functioning of children provided with kangaroo mother care and those who were not provided with this kind of care?

2. Will it be possible to observe, in a nursery school period, differences in the social-emotional functioning and the possible intensification of emotional difficulties and in the behaviour in the group of children provided with kangaroo mother care and those who were not provided with this kind of care?

3. Does the occurrence of IVH exert an influence on the reduction of possible emotional or cognitive difficulties in the group of children in question?

\section{PARTICIPANTS AND PROCEDURE}

\section{PROCEDURE}

In the research, the tools serving to conduct the assessment of the cognitive development of children at nursery school age, and also data obtained in the course of an interview with the mother of a child, based on the Rescorla DSM-IV Oriented Scales (2005), were used. Below, these tools are described in detail: 
Re 1) The assessment of the cognitive-intellectual development of the researched children:

- the Terman-Merrill Scale (Terman \& Merrill, 1959) makes it possible to determine the development of particular functions of which general intellectual development is composed, such as: verbal skills, operational thinking, short-term memory, ability to concentrate attention, manual and graphomotor dexterity, visual-motor coordination, and logical thinking skill.

For the purpose of interpretation of the Terman-Merrill Scale, the Walet Scale Interpretation System was used. This system differentiates between the particular subtests of the Terman-Merrill Scale in accordance with Six Interpretation Factors. In order to assess verbal skills, the results from two factors assessing verbal skills were summed up, namely from: ability to understand the meaning of words, sentences and phrases; and lexical and verbal fluency.

- Columbia Mental Maturity Scale

The Columbia Mental Maturity Scale (Ciechanowicz, 1990) was developed in order to research the mental capacities of children suffering from cerebral palsy, or different handicaps causing the weaker development of motor and verbal functions. The tasks set for this scale were formulated in such a way as to make it possible to research both healthy and disabled children. Because preterm infants function at quite a varied motor skills level, it was resolved that this tool would be selected for the purpose of the assessment of intellectual development. The research conducted recently (Szychowiak, 2004) confirms the diagnostic validity of the Columbia Mental Maturity Scale for the investigation of the abilities possessed by a child in the scope of ordering the world and drawing conclusions.

- An interview based on the DSM-IV Oriented Scales for Boys and Girls

In order to develop the interview, the translation of the DSM-IV Oriented Scales for Boys and Girls based on the Child Behavior Checklist (CBCL 1.5-5), which was published by L. Rescorla in 'Mental Retardation and Developmental Disabilities Research Reviews' in 2005, was used. The objective of the Scale is to facilitate the formulation of a diagnosis on the basis of the nosological units which are currently mandatory. Sixteen experienced child psychiatrists and psychologists, representing 10 cultures, were requested to assess each of the 99 statements in the CBCL 1.5-5 as incompatible, partly compatible or greatly compatible with each of the 9 categories of the DSM-IV (Rescorla, 2005). Subpoints which were assessed as 'greatly compatible' with a certain category of the DSM by no fewer than 10 out of 16 experts were included in the Scale (Rescorla, 2005, p. 231). The assessment conducted by experts resulted in the division of the 9 categories of the DSM into the following 5 scales:
1. The Depressive Disorder Scale (which includes depressive, and also dysthymic, disorders);

2. The Anxiety Disorder Scale (which includes separation disorders, and also phobias);

3. The Attention-Deficit and Hyperkinetic Behaviours Scale;

4. The Pervasive Developmental Disorder Scale (which includes Asperger disorder, and also early-childhood autism);

5. The Oppositional-Defiant Behaviours Scale.

The results measured using the DSM-IV Oriented Scales for Boys and Girls are not identical to the diagnosis of certain developmental disorders in accordance with the criteria in the DSM-IV. The scales do not precisely match the 9 categories of the DSM-IV; DSM-IV Oriented Scales for Boys and Girls are based on the qualitative analysis, whereas the diagnosis using the DSM is based on the occurrence of certain symptoms, or the lack of it. The obtained results come from, first and foremost, parents and caregivers, and therefore they may differ depending on who the informing person was in terms of the functioning of a child (Rescorla, 2005). An interview with the mothers of the researched children. The data concerning kangaroo mother care in the case of a child in the course of being hospitalized, and also the frequency of kangaroo mother care, were obtained in the course of an interview.

\section{PARTICIPANTS}

The research was participated in by 99 preterm infants, and also by their mothers. Fifty-three of the children were provided with kangaroo mother care since the moment of attaining respiratory independence with the frequency of no fewer than twice a week. Forty-six of the children did not take advantage of this kind of care, or did it sporadically, most frequently a few days before being discharged.

In the researched population, the shortest duration of a pregnancy was 26 weeks, whereas the longest one was 36 weeks. Differentiation in the criterion group due to maturity at the moment of giving birth determines the possible future consequences of a preterm birth. The average duration of the stay of a child at the intensive care ward, or at the preterm infant ward, at which the researched children were hospitalized, was 40.53 days $(S D=44.93)$, and the average duration of the stay in an incubator was 21.21 days $(S D=26.00)$. The average number of days of mechanical ventilation was 7.43 days $(S D=18.99)$. Retinopathy of prematurity was diagnosed in the case of 27 of the children, which constitutes $26.73 \%$ of the group. Retinopathy of first degree occurred in 13 of the children, of the second degree in 7 , of the third degree in 5 , and of the fourth degree in 2 of them. Three of the researched children are blind. Child cerebral
The effects of kangaroo mother care 
Table 1

Group characteristics

\begin{tabular}{ccc}
\hline & \multicolumn{2}{c}{ Preterm infants } \\
\hline $\begin{array}{c}\text { Intelligence quotient } \\
\text { on the basis of the Columbia } \\
\text { Mental Maturity Scale }\end{array}$ & $n$ & $\%$ \\
\hline$<69$ & 18 & 18.60 \\
$70-84$ & 13 & 13.40 \\
$85-114$ & 53 & 54.60 \\
$>115$ & 13 & 13.40 \\
\hline
\end{tabular}

palsy occurred in 13 of the children, and epilepsy in 11 of them. Effusion into the structures of the brain occurred in 29 of the children, which constitutes approximately $28.71 \%$ of the group. Effusion of the first degree was experienced by 12 of the children, of the second degree by 8 , of the third degree by 6 , and of the fourth degree by 3 of them. Post-haemorrhagic hydrocephalus, a consequence of an intraventricular haemorrhage, occurred in 7 of the children. Periventricular leukomalacia (PVL) occurred in 10 of the children.

\section{KANGAROO MOTHER CARE AND THE COGNITIVE DEVELOPMENT OF THE RESEARCHED CHILDREN}

The profile of the cognitive functioning of the researched children is presented in Table 1. Sixty-eight percent of the researched children were characterized by average, or higher than average, intelligence quotient; however, as many as $32 \%$ of the children obtained results lower than average.

Kangaroo mother care did not turn out to be connected with the cognitive development of children in a statistically significant way. In accordance with the expectations and the review of the literature, it was observed that there existed (Bidzan \& Bieleninik,
2013) a connection between the level of the cognitive development of a child and the occurrence of early damage to the brain. Children suffering from IVH experienced significantly greater difficulties in 5 out of the 7 categories being assessed. Children suffering from IVH in both of the researched groups (both provided with kangaroo mother care, and not provided with it) obtained significantly lower results in the subtest assessing the skills of understanding the meaning of words, sentences and phrases $(p=.049)$ than preterm infants not suffering from IVH. Children suffering from IVH obtained, as well, a significantly lower $(p=.038)$ average score on the subscale assessing arithmetic reasoning than children who had not suffered from a haemorrhage. Children suffering from IVH coped significantly worse ( $p=.023)$ with the tasks requiring memory, and also the concentration of attention, and obtained significantly worse $(p=.016)$ results in the subtests assessing the lexicon, and also verbal fluency, than children in whose case early damage to the brain had not occurred. Intraventricular hemorrhage exerted a statistically significant $(p=.034)$ influence on the lower level of the skills of judgement and reasoning, namely concerning processes connected with the operational thinking which was developing at that time.

\section{KANGAROO MOTHER CARE AND THE EMOTIONAL-SOCIAL DEVELOPMENT OF THE RESEARCHED CHILDREN}

Table 2 presents the profile of the emotional-social functioning, and also the percentage distribution of the researched children, whose results represented the clinical and subclinical range of the DSM-IV Oriented Scales for Boys and Girls.

Due to the heterogeneousness of the researched group - for example, $30 \%$ of the researched children had experienced early damage to the brain - we performed an additional variance analysis of the connection between an IVH and the results of the emotional-social functioning of the children, the description

Table 2

Data on the number of children with increased results in individual subscales of DSM-IV Oriented Scales for Boys and Girls

\begin{tabular}{lcc}
\hline \multicolumn{1}{c}{ DSM-IV Oriented Scales for Boys and Girls } & \multicolumn{2}{c}{ Preterm infants } \\
\cline { 2 - 3 } & Number of children & 19.80 \\
\hline Depressive disorder scale & 20 & 35.64 \\
Pervasive developmental disorder scale & 36 & 15.94 \\
Oppositional-defiant behaviours & 16 & 12.87 \\
Hyperkinetic disorder scale & 13 & 28.71 \\
Anxiety disorder scale & 29 & \\
\hline
\end{tabular}


of which was obtained on the basis of an interview with mothers based on the DSM-IV Oriented Scale for Boys and Girls. The conducted variance analysis indicated the intensification (at the level of a tendency) of depressive disorders in the group of children suffering from haemorrhages of the first and fourth degrees, and also preterm infants, in whose case early damage to the brain had not occurred. The children who had suffered from effusion of the first degree $(M=4.30, S D=3.40)$, of the fourth degree $(M=4.67$, $S D=1.15)$, and also preterm infants, in whose case effusion had not occurred $(M=3.50, S D=2.35)$ obtained, bordering on a statistical tendency, results lower than those of children suffering from haemorrhage of the second degree $(M=2.17, S D=1.17)$ and of the third degree $(M=1.20, S D=1.79)$. That means that in the researched sample preterm infants in whose case early damage to the brain had not occurred, suffering from IVH I, and also of IVH IV, are characterized by a greater intensification of behaviours connected with the experience of a deteriorated mood. On the remaining subscales of the DSM-IV Oriented Scale for Boys and Girls, the researched children did not show statistically significant differences in terms of their results.

In order to assess the connection between kangaroo mother care and the results obtained by children using the DSM-IV Oriented Scale for Boys and Girls, a two-factor analysis of variance $2 \times 2$ with the intergroup factors of kangaroo mother care, and also early damage to the brain, was conducted. The results of it are presented in Table 3.

The analysis showed the connection between kangaroo mother care and the score in the category assessing anxiety disorders, and also depressive disorders. Children provided with kangaroo mother care - both those who had not suffered from effusion $(M=4.82, S D=3.63)$, and these who had suffered from IVH $(M=5.33, S D=1.37)$ - were characterized by significantly lower results $(p=.044)$ than preterm infants who had suffered from IVH $(M=9.00$, $S D=5.33)$ and who had not $(M=6.06, S D=3.39)$, who were not provided with this opportunity to contact their parents. Preterm infants who had been provided with kangaroo mother care and had undergone effusion $(M=48.33, S D=12.55)$ or not $(M=45.41$, $S D=18.75)$ were characterized by significantly lower $(p=.032)$ intensification of symptoms connected with elevated level of depression than that found in the case of children who had suffered from effusion $(M=8.17, S D=5.23)$, and also than children who had not $(M=56.56, S D=30.84)$ and who had not been provided with kangaroo mother care in the course of being hospitalized.

What was observed as well, was the connection between IVH and the intensification of symptoms connected with pervasive developmental disorders. The obtained result is compatible with clinical observations: these problems occur more frequently in the case of children having low birth weight (Pisu-

Table 3

Results of the $2 \times 2$ two-factor variance analysis with the intergroup factors of kangaroo mother care, and also early damage to the brain in the form of IVH, on the emotional-social development of the researched preterm infants

\begin{tabular}{|c|c|c|c|c|c|c|c|c|c|c|c|c|c|c|}
\hline & \multicolumn{4}{|c|}{$\begin{array}{l}\text { Kangarooed } \\
\text { children }\end{array}$} & \multicolumn{4}{|c|}{$\begin{array}{c}\text { Not kangarooed } \\
\text { children }\end{array}$} & \multicolumn{6}{|c|}{ Significance of differences } \\
\hline & \multicolumn{2}{|c|}{$\begin{array}{l}\text { Lack of } \\
\text { IVH }\end{array}$} & \multicolumn{2}{|c|}{$\mathrm{IVH}$} & \multicolumn{2}{|c|}{$\begin{array}{l}\text { Lack of } \\
\text { IVH }\end{array}$} & \multicolumn{2}{|c|}{$\mathrm{IVH}$} & \multicolumn{2}{|c|}{$\begin{array}{c}\text { Effect } \\
\text { of mother } \\
\text { kangaroo care }\end{array}$} & \multicolumn{2}{|c|}{$\begin{array}{l}\text { Effect } \\
\text { of IVH }\end{array}$} & \multicolumn{2}{|c|}{$\begin{array}{c}\text { Effect } \\
\text { of interaction }\end{array}$} \\
\hline & $M$ & $S D$ & $M$ & $S D$ & $M$ & $S D$ & $M$ & $S D$ & $\begin{array}{c}F \\
(1,125) \\
\end{array}$ & $p$ & $\begin{array}{c}F \\
(1,127)\end{array}$ & $p$ & $\begin{array}{c}F \\
(3,125)\end{array}$ & $p$ \\
\hline $\begin{array}{l}\text { Depressive } \\
\text { disorder scale }\end{array}$ & 5.45 & 2.96 & 3.33 & 1.21 & 5.22 & 2.98 & 8.17 & 5.23 & 4.89 & $.032^{*}$ & 0.16 & .694 & 5.92 & .019 \\
\hline $\begin{array}{l}\text { Anxiety } \\
\text { disorder scale }\end{array}$ & 4.82 & 3.63 & 5.33 & 1.37 & 6.06 & 3.39 & 9.00 & 5.33 & 4.26 & $.044^{*}$ & 2.12 & .152 & 1.05 & .312 \\
\hline $\begin{array}{l}\text { Pervasive } \\
\text { developmental } \\
\text { disorder scale }\end{array}$ & 3.59 & 2.84 & 8.83 & 5.31 & 7.50 & 5.50 & 8.67 & 5.50 & 1.59 & .214 & 4.65 & $.036^{*}$ & 1.88 & .177 \\
\hline $\begin{array}{l}\text { Hyperkinetic } \\
\text { disorder scale }\end{array}$ & 6.82 & 2.46 & 5.00 & 1.41 & 6.78 & 2.76 & 7.33 & 2.80 & 1.90 & .174 & 0.58 & .451 & 2.04 & .160 \\
\hline $\begin{array}{l}\text { Oppositional- } \\
\text { defiant } \\
\text { behaviours }\end{array}$ & 4.64 & 2.75 & 4.33 & 3.61 & 4.50 & 3.35 & 5.67 & 4.18 & 0.32 & .577 & 0.16 & .687 & 0.48 & .494 \\
\hline
\end{tabular}


la, 2003). Children suffering from IVH are generally characterized by a lower birth weight than children in whose case complications of that kind had not occurred. The obtained results indicate that early damage to the brain may be connected with the occurrence of disorders of this type. Due to the small population included in this research project, conducting further research is worth recommending. Perhaps a larger sample would make it possible to obtain information about statistically significant correlations.

\section{DISCUSSION}

The conducted research confirmed the protective function of kangaroo mother care for the emotional-social development of the researched preterm infants at nursery school age. In the discussed research, contrary to the results presented in the theoretical part (Feldman et al., 2014; Tessier et al., 2003), no connection between early skin-to-skin contact with the cognitive development of a child was observed. The obtained results may, however, be connected with the tools used in the research: in the course of the research conducted by the Feldman et al. (2014) team, there were no significant intergroup differences between children provided with kangaroo mother care and not provided with it as far as the results of tests assessing intelligence are concerned. The observed differences were relevant to results on the scales assessing executive functions connected with cognitive control; however, these abilities were not assessed in our research.

Nevertheless, in our own research, the connection between early skin-to-skin contact and the emotional-social functioning of the researched children was observed. Children who were provided with kangaroo mother care experienced a smaller number of anxiety disorders, and also depressive ones, at nursery school age. For clinical practice, a particularly significant issue seems to be the result relevant to lowered score in the subtest assessing depressive disorders in the group of children provided with kangaroo mother care who had experienced early damage to the brain in the form of IVH. In the researched sample, early damage to the brain (IVH I and IVH IV) was connected with an elevated level of depression; kangaroo mother care moderates this connection.

The obtained results may be connected with the (presented in the introduction) research showing the protective (anti-stress and anti-pain) function of kangaroo mother care. Early and repeated pain stimuli exert an influence on the later behaviour of a child (Gruntau et al., 2014, quoting: Champion, 2005; Anand \& Scalzo, 2000). The short-term consequences of the time-extended feeling of pain and discomfort include, among others, changes in the interactions between a neonate and their environment, reducing their ability to become involved and maintain contact with the parents. In certain situations, that may exert an influence on the developing relationships between parents and a neonate, and also the quality of attachment in the parents-children triad. Consequently, a child may be deprived of the possibility of regulating tension, resulting in the risk of problems with the regulation of emotions, among others, the more frequent experience of fear, anxiety and depressiveness. Therefore, kangaroo mother care, by means of supporting the ability of a child to regulate their own states as soon as at the early stages of their life, might have exerted an influence on the mental immunity of the researched children and their better coping with fear and anxiety in the period of attending nursery school.

On the other hand, kangaroo mother care also exerts an influence on the welfare of mothers of preterm infants; this form of care is connected with a lowered level of depressiveness and fear (among others, Tallandini \& Scalambra, 2006; Barratt et al., 1992; Brooten et al., 1988). The research indicates the connection between a mother's depression and the further functioning of a child, as well as with the development of bonds in the mother-child dyad (Galler, Harrison, Ramsey, Forde, \& Butler, 2000; Jones et al., 1998; Chrzan-Dętkoś, Dyduch-Maroszek, Humięcka, \& Karasiewicz, 2012). Kangaroo mother care, lowering the symptoms of depressions in the case of a mother, may fulfil a significant protective function. This connection is particularly noticeable in the case of children having negative neurological history: a mother's depression may be an additional environmental risk factor in the case of preterm infants who had experienced early damage to the brain, and who may have more problems with the initiation of social interactions. The occurrence of IVH, in combination with the conditions resulting from a mother's history, were connected with the later disorganized attachment in the case of a child (Cox et al., 2000). As well as that, the research by the team of Van Ijzendoorn, Goldberg, Kroonenberg, \& Frenkel (1992) indicates that children with medical problems, or neurological ones, belonging to the risk group of problems with the creation of bonds, are more frequently diagnosed as suffering from a disorganized bond, which is a risk factor of psychopathology in the case of a child.

On the basis of the available literature, it is possible to formulate a hypothesis, which, however, would require further research, that the obtained elevated result of the intensity of the symptoms of depression in the group of children who had experienced early damage to the brain may be connected with the quality of the style of attachment between a mother and a child, and that kangaroo mother care may, in certain situations, eliminate both a depressive state in the case of a mother, and the influence exerted by 
such a state on the development of a neonate. Kangaroo mother care may also directly change the style of a mother's coping with her child's being hospitalized and medical condition, as well as exert an influence on interactions in the triad (Feldman et al., 2002). Clinical observations, as well as the results of research, show that mothers are glad to be able to take advantage of kangaroo mother care, and that they willingly use this opportunity to contact their children (Broughton et al., 2013). That fact is important, because research (Kmita, 2003) shows that the greater involvement of parents in the treatment of their child is connected with the better cognitive development of the child throughout the first year of their life. The results of research are also backed up by what the researched mothers themselves said.

The mother of Krzysztof, born in the $24^{\text {th }}$ week of pregnancy, whose birth weight was 600 grams, reminisced, 'We had been able to provide kangaroo mother care for Krzyś since his weight reached 1,500 grams. It was an unusual experience for me, to finally pick him up for a longer time - although already earlier I had sometimes been allowed by nurses to hold him for a little while. We would come to visit him twice a day. I remember that one day we couldn't come, as the older son was unwell, and we were afraid we would infect Krzyś with something, and, please, imagine that our son had 'a breakdown' on that day - he got apnoeas, and he had to be given a face tent mask again. I told my husband: I think he missed us. And indeed, the next day, because, of course, we came at once, there were no breathing problems... And there were no more of them, not to a disturbing degree, until the end of Krzyś' stay at the ward, but we would come every day to him since that time on!'.

'When I was providing kangaroo mother care for Ania for the first time, I was a little bit worried. I had been waiting for that for so long!' recalls the mother of Ania, born in the $24^{\text {th }}$ week of pregnancy, with birth weight of 540 grams. 'On the one hand, I wanted to touch her so very much, but she was so small, and her skin seemed to be so very thin. I think that, when the first time came, she felt I was afraid that I would drop her, I was afraid that my way of holding her would be uncomfortable for Ania... but on the next day there were already no such emotions. My husband and I provided kangaroo mother care for her at least once a day, and it did start a change of our behaviour at the ward. We did not just look at her through the window any more, but, at least, we could be with her a little, like the parents of a healthy child....

The review of the literature and the results of our own research indicate the long-term and beneficial influences of kangaroo mother care. By means of the hypothetical, two-way influence, encompassing both the self-regulation skills of a child and the welfare of a mother, kangaroo mother care seems to support the developing competences of a child to cope with their own emotional states.

Kangaroo mother care, which, at the level of the work organization of neonatal wards, is not connected with the additional costs of child's treatment, provides immediate health benefits for the child and the mother, and it seems also to support the mental immunity of a child. Research shows, however, that the consequences reach beyond the sphere of the survival of a child, and exert an influence on their welfare in the following years of life, regardless of the level of income in a given country.

\section{CONCLUSIONS}

In the course of our own research, preterm infants provided with kangaroo mother care in a nursery school period experienced a significantly smaller number of internalizing symptoms: a smaller number of anxiety and depressive disorders than preterm infants who were not provided with this kind of care. A particular result was observed in the group of children who had suffered from early damage to the brain: the occurrence of IVH in the researched sample was connected with the elevated level of depressiveness, whereas kangaroo mother care eliminated this connection.

\section{REFERENCES}

Anand, K. J., \& Scalzo, F. M. (2000). Can adverse neonatal experiences alter brain development and subsequent behavior? Biology of Neonate, 77, 69-82.

Barker, D., \& Rutter, N. (1995). Exposure to invasive procedures in NICU admissions. Journal of Archives of Disabled Children: Fetal Neonatal Education, 55, 1877-1884.

Barratt, M. S., Roach, M. A., \& Leavitt, L. A. (1992). Early channels of mother-infant communication: preterm and term infants. Journal of Child Psychology \& Psychiatry, 33, 1193-1204.

Brooten, D., Gennaro, S., Brown, L. P., Butts, P., Gibbons, A. L., Bakewell-Sachs, S., \& Kumar, S. P. (1988). Anxiety, depression, and hostility in mothers of preterm infants. Nursing Research, 37, 213-216.

Beckwith, L., \& Parmelee, A. (1986). EEG patterns of preterm infants, home environment and later IQ. Child Development, 57, 777-789.

Bhutta, A. T., Cleves, M. A., Casey, P. H., Cradock, M. M., \& Anand, K. J. (2002). Cognitive and behavioral outcomes of school-aged children who were born preterm: a meta-analysis. The Journal of American Medical Association, 288, 728-737.

Bidzan, M., \& Bieleninik, Ł. (2013). Psychomotor development of preterm babies in the context of biomedical predictors in Polish sample.
The effects of kangaroo mother care 
Health Psychology Report, 1, 18-33. DOI: 10.5114/ hpr.2013.40466

Bidzan, M., Bieleninik, Ł., \& Lipowska, M. (2013). The development of speech in early childhood in children from twin pregnancies with twin-twin transfusion syndrome. Polish Psychological Bulletin, 44, 9-20. DOI: 10.2478/ppb-2013-002

Blencowe, H., Cousens, S., Chou, D., Oestergaard, M., Say, L., Moller, A. B., Kinney, M., \& Lawn, J. (2013). Born too soon: global epidemiology of 15 million preterm births. Reproductive Health, 10 (Suppl 1): S2. DOI: 10.1186/1742-4755-10-S1-S2

Brisch, K., et al. (2005). Attachment Quality in Very Low-Birthweight Premature Infants in Relation to Maternal Attachment Representations and Neurological Development. Parenting: Science and Practice, 5, 311-331.

Brouhton, E. I., Gomez, I., Sanchez, N., \& Vindell, C. (2013). The cost-savings of implementing kangaroo mother care in Nicaragua. Revista Panamericana de Salud Publica, 34, 176-182.

Champion, P. (2005). The at-risk infant - approaches to intervention. The Champion Centre Model. In: Carpenter, B. \& Egerton, J. (eds.), Early Childhood Intervention. International Perspectives, National Initiatives and Regional Practice (pp. 39-52). Wielka Brytania:West Midlands Sen Regional Partnership.

Chrzan-Dętkoś, M. (2012). Wcześniaki. Rozwój psychoruchowy w pierwszych latach życia [The preterm child. Psychomotor development in the first years of life]. Gdańsk: Harmonia Universalis.

Chrzan-Dętkoś, M., Dyduch-Maroszek, A., Humięcka, A., \& Karasiewicz, K. (2012). Uwarunkowania i konsekwencje depresji poporodowej - badania pilotażowe [Psychological background of post-partum depression and it's consequences]. Psychoterapia, 161, 55-63.

Chrzan-Dętkoś, M., \& Bogdanowicz, M. (2009). Rozwój poznawczy i emocjonalno-społeczny wcześniaków w wieku przedszkolnym [Cognitive and socio-emotional development of preschool-aged preterm children]. Pediatria Polska, 84, 517-523.

Ciechanowicz, A. (1990). Skala Dojrzałości Umystowej Columbia [Columbia Mental Maturity Scale]. Warszawa: Pracowania Testów Psychologicznych PTP.

Cox, S., Hopkins, J., \& Hans, S. (2000). Attachment in preterm infants and their Mothers: neonatal risk status and Maternal representations. Infant Mental Health Journal, 21, 464-480.

Engmann, C., Wall, S., Darmstadt, G., Valsangkar, B., \& Claeso, M. Participants of the Istanbul KMC Acceleration Meeting (2013). Consensus on kangaroo mother care acceleration. The Lancet, 382; 26-27. DOI: 10.1016/S0140-6736(13)62293-X

Feldman, R., Rosenthal, Z., Eidelman, A. (2014). Maternal-preterm skin-to-skin contact enhances child physiologic organization and cognitive control across the first 10 years of life. Biolo- gical Psychiatry, 75, 56-64 DOI: 10.1016/j.biopsych. 2013.08.012.

Feldman, R., Weller, A., Sirota, L., \& Eidelman, A. I. (2002). Skin-to-skin contact (Kangaroo Care) promotes self-regulation in premature infants: Sleepwake cyclicity, arousal modulation, and sustained exploration. Developmental Psychology, 38, 194-207.

Galler, J. R., Harrison, R. H., Ramsey, F., Forde, V., \& Butler, S. C. (2000). Maternal depressive symptoms affect infant cognitive development in Barbados. Journal of Child Psychology and Psychiatry, 41, 747-757.

Garcia-Coll, C., Emmons, L., \& Vohr, B. R. (1988). Behavioural responsiveness in preterm infants with intraventricular hemmorrhage. Pediatrics, 81, 412-418.

Gerhardt, S. (2010). Znaczenie mitości. Jak uczucia wptywaja na rozwój mózgu [Why love matters: how affection shapes a baby's brain]. Kraków: Wydawnictwo Uniwersytetu Jagiellońskiego.

Glover, V., Miles, R., Matta, S., Modi, N., \& Stevenson J. (2005). Glucocorticoid exposure in preterm babies predicts saliva cortisol response to immunisation at 4 months. Pediatric Research, 58, 1233-1237.

Grunau, R. E., Tu, M. T., Whitfield, M., Oberlander, T., Weinberg, J., Yu, W., Thiessen, P., Gosse, G., \& Scheifele, D. (2010). Cortisol, behavior, and heart rate reactivity to immunization pain at 4 months corrected age in infants born very preterm. The Clinical Journal of Pain, 26, 698-704.

Helwich, E. (ed.). (2002). Wcześniak [The preterm infants]. Warszawa: PZWL.

Hofer, M. A. (1987). Early social relationships: a psychobiologist's view. Child Development, 58, 633-647.

Hofer, M. A., \& Shair, H. (1982). Control of sleepwake states in the infant rat by features of the mother-infant relationship. Developmental Psychobiology, 15, 229-243.

Johnston, C. C., Stevens, B., Pinelli, J., Gibbins, S., Filion, F., Jack, A., Steele, S., Boyer, K., \& Veilleux, A. (2003). Kangaroo care is effective in diminishing pain response in preterm neonates. Archives of Pediatrics \& Adolescent Medicine, 157, 1084-1088.

Johnston, C. C., Filion, F., Campbell-Yeo, M., Goulet, C., Bell, L., McNaughton, K., \& Byron J. (2009). Enhanced kangaroo mother care for heel lance in preterm neonates: a crossover trial. Journal of Perinatology, 29, 51-56.

Johnston, C. C., Filion, F., Campbell-Yeo, M., Goulet, C., Bell, L., McNaughton, K., Byron, J., Aita, M., Finley, G. A., \& Walker, C. D. (2008). Kangaroo mother care diminishes pain from heel lance in very preterm neonates: a crossover trial. $B M C$ Pediatrics, 8, 13. DOI: 10.1186/1471-2431-8-13

Jones, J. A., Field, T., Fox, N. A., Davalos, M., Lundy, B., \& Hart, S. (1998). Newborns of mothers with depressive symptoms are physiologically less developed. Infant Behavior \& Development, 21, 537-541. 
Kmita, G. (2003). Trauma przedwczesnych narodzin: Procesy radzenia sobie rodziców a rozwój dziecka. Wybrane aspekty metodologiczne i statystyczne pracy doktorskiej. Materiaty z konferencji: Zastosowanie metod statystycznych w badaniach naukowych [The trauma of premature birth. Coping processes in parents and the child's development. Selected aspects of the methodological and statistical doctoral dissertation. Materials from the conference: Application statistical methods in research]. Statsoft Polska.

Nyqvist, K. H., Anderson, G. C., Bergman, N., Cattaneo, A., Charpak, N., Davanzo, R., Ewald, U., Ibe, O., Ludington-Hoe, S., Mendoza, S., PallásAllonso, C., Ruiz Peláez, J. G., Sizun, J., \& Widström, A. M. (2010). Towards universal Kangaroo Mother Care: recommendations and report from the First European conference and Seventh International Workshop on Kangaroo Mother Care. Acta Pædiatrica, 99, 820-826. DOI: 10.1111/j.1651-2227.2010.01787.x

Pisula, E. (2003). Autyzm i przywiazanie. Studia nad interakcjami dzieci z autyzmem i ich matek [Autism and attachment, mothers and children with autism interactions studies]. Gdańsk: Gdańskie Wydawnictwo Psychologiczne.

Rescorla, L. (2005). Assessment of young children using the achenbach system of empirically based assessment (ASEBA). Mental Retardation and Developmental Disabilities Reaserch Reviewes, 11, 226-237.

Szychowiak, B. (2004). Możliwości i ograniczenia wynikające z zastosowania skali Dojrzałości Umysłowej Columbia do badania dzieci z głębszą niepełnosprawnością intelektualną [The possibilities and limitations of the application of the Columbia Mental Maturity Scale in the assessment of children with profound intellectual disabilities]. Wczesna diagnoza i terapia dzieci z utrudnieniami rozwoju. Interdyscyplinarne problemy [Early diagnosis and therapy of children with developmental difficulties. The interdisciplinary problems]. Wrocław: Dolnośląska Szkoła Wyższa Edukacji Towarzystwa Wiedzy Powszechnej.

Tallandini, M. A., \& Scalembra, Ch. (2006). Kangaroo mother care and mother-premature infant dyadic interaction. Infant Mental Health Journal, 27, 251275. DOI: 10.1002/imhj.20091

Terman, L. M., \& Merrill, M. A. (1959). Skala Inteligencji [The Intelligence Scale]. Warszawa: Ministerstwo Oświaty.

Tessier, R., Cristo, M. B., Velez, S., Giron, M., Nadeau, L., Figueroa de Calume, Z., Ruiz-Paláez, J., \& Charpak, N. (2003). Kangaroo mother care: A method for protecting high-risk low-birth-weight and premature infants against developmental delay. Infant Behavior and Development, 26, 304-397.

Worku, B., \& Kassie, A. (2005). Kangaroo mother care: a randomized controlled trial on effectiveness of early kangaroo mother care for the low birthweight infants in Addis Ababa, Ethiopia. Journal of Tropical Pediatrics, 51, 93-97. DOI: 10.1093/tropej/fmh085

Van ljzendoorn, M. H., Goldberg, S., Kroonenberg, P. M., \& Frenkel, O. J. (1992). The relative effects of maternal and child problems on the quality of attachment: A meta-analysis of attachment in clinical samples. Child Development, 63, 840-885.
The effects of kangaroo mother care 